Conference Paper

\title{
The Impact of Remittance toward Indonesia's Economic Growth
}

\author{
Nur Siti Annazah*, Ivan Suryono \\ Kementerian Ketenagakerjaan Republik Indonesia, Jakarta, Indonesia
}

*Corresponding author:

E-mail: anazah.siti@gmail.com

\begin{abstract}
This paper aims to find out external factor toward long-term economic growth. Variable used are remittance, PMTB, import and economic growth obtained from World Development Indicator (WDI) in period of 1988-2018. Regression analysis of ARDL Cointegration is utilized in finding out remittance, PMTB and import toward economic growth both for short-term and long-term. The result of analysis shows that remittance affects toward long-term economic growth. PMTB variable can increase economic growth both for short-term and long-term. Import variable can increase economic growth in short-term, but it decreases economic growth in long-term. The result shows that external factors need to be paid attention more by government because it can contribute toward national economic growth
\end{abstract}

Keywords: Auto Regressive Distributed Lag (ARDL), Economic Growth, Remittance, Indonesia.

\section{Introduction}

Indonesia as developing country strongly maintain the momentum of economic growth amid the growing global economic uncertainty. By maintaining an economic growth rate of 5\% per year, it made Indonesia became the country with the most stable economic growth since 2002 (Burke \& Siyaranamual, 2019). Sustainable economic growth becomes important especially in developing countries because it can reduce poverty and improve the quality of life of people through the education and health sectors. Economic growth is influenced by several factors. The domestic factors such as savings and human capital are important factors in achieving economic growth (Mankiw et al., 1992).

Current account deficit has been become a serious problem. This resulted in the depreciation of the rupiah. Bank Indonesia Deputy Governor, Sugeng, revealed that one of the ways to save the CAD from being too wide is to increase remittances from abroad to the country. ${ }^{2}$ Remittances which enter in Indonesia have also generated substantial foreign exchange. Figure 1 explains that remittances entering Indonesia increased from 2005 to 2018. However, in 2016, the number of remittances decreased due to the moratorium on illegal migrant workers to the Middle East. Migration also had impacts form the Indonesian economy; in 2016, migrant workers sent remittances worth more than IDR 118 trillion (USD8.9 billion), or equivalent to 1\% of Indonesia's total GDP (World Bank, 2017). 


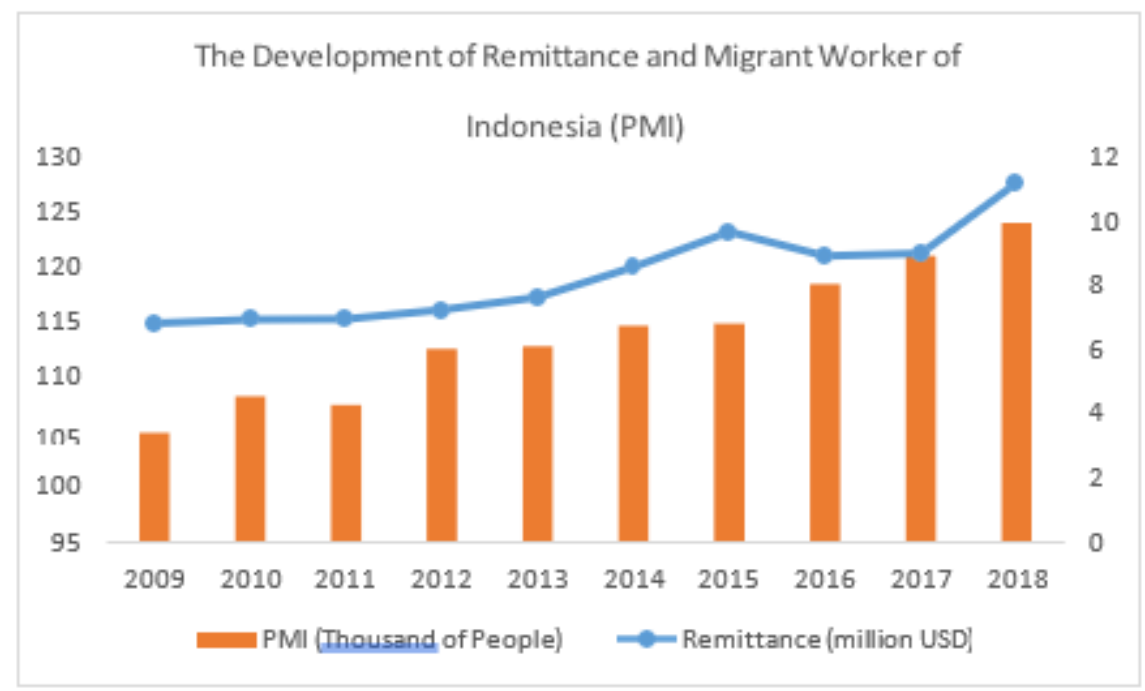

Figure 1. the development of Remittance and Migran worker of Indonesia in 2005-2018 (Source: World Development Indicators, 2019)

The momentum of economic recovery in some countries amid rising global uncertainty. The economic slowdown is affected by slowing global economic growth, especially China. In addition, the trade war occurred between China and the United States also poses a great risk which can be a threat to economic growth. To be able to maintain good economic growth momentum, Indonesia continues to strive to achieve ideal economic conditions. In this condition of economic growth, Indonesia needs to pay attention to other external factors such as remittances, investment and imports which are also important factors in increasing economic growth (Tahir et al., 2015; Driffield \& Jones 2013; Issahaku et al., 2018).

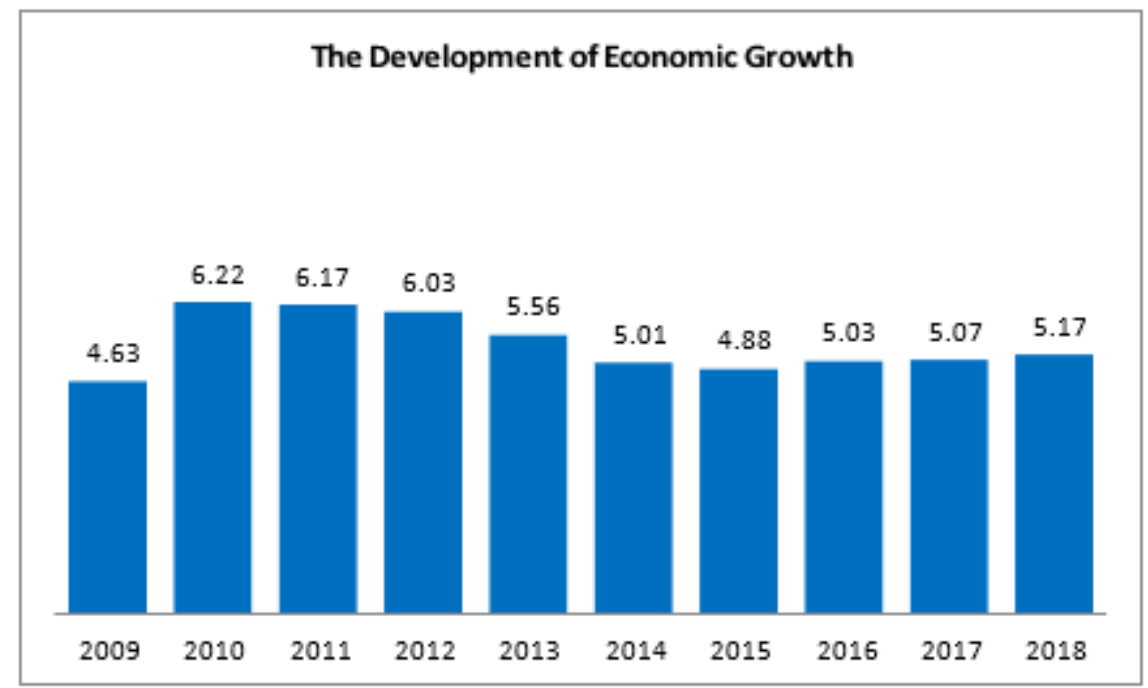

Figure 2. The Development of Indonesia's Economic Growth in 2009-2018 (Source: World Development Indicators, 2019)

Indonesia's economic growth in 2018 was $5.17 \%$. It had enhancement than the provious year of $5.07 \%$ (Figure 2). Economic growth in 2018 was the highest growth since 2013. In general, this performance shows the Indonesian economy remains solid, bearing in mind that at the same time the world economic growth in 2018 is on a slowing trend and global uncertainties are increasing (Bank Indonesia, 
2019). Indonesia has also succeeded in attracting a number of investments, both directly from foreign and domestic investors in the form of fixed capital. In addition, imports also certainly play a role in economic growth because Indonesia depends on imports, especially for primary good. Therefore, the author tries to build a hypothesis related to the relationship between remittances, Gross Fixed Capital Formation (PMTB), imports, and economic growth which certainly can provide input to policy makers.

The research of remittance has been still about the relation of causality between remittance and economic growth. Remittance studies generally depart from the assumption that remittance inflows (remmitance infloe) affect the level of economic growth in the recipient country. There are three perspectives in addressing these assumptions. The first group argues that remittances can have a positive impact on economic growth and prove it through empirical research (Giuliano \& Ruiz-Arranz, 2009; Beck et al., 2007; Tahir et al., 2015; Sinha, et al., 2019). The second group questions these assumptions and argues that remittances can only affect economic growth under certain conditions or in relation to other variables (Issahaku \& Amidu, 2018; Bettin \& Zazzaro, 2011). The third group recognizes that remittances can have a positive impact on economic growth but also have a negative impact by reducing worker productivity (Sharma 2018; Chami et al., 2003).

The interesting question is "Are external factors such as remittance affect toward economic growth in Indinesia?". To carry out the analysis, the research uses secondary data obtained from the World Development Indicator (WDI), which are economic growth, remittances, imports, and PMTB in the period 1980-2018. This paper also offers a renewal of the impact of remittances on economic growth in Indonesia by considering the period (short and long term).

The discussion will be organized into five sections. The first part is the background of the research, the second part is Literature Review which discusses relevant literature. Furthermore, the methodology is explained in the third part. The results and discussion are presented in the fourth part. Finally, the fifth part concludes and provides policy recommendations.

\section{Literature Review}

Indonesian international labor migration gives a huge contribution for the lives of many mi-grant workers, their families and also the Indonesian economy. There are more than 9 million Indonesian citizens working abroad, of almost 7\% of the total Indonesian workforce (World Bank, 2017). Remittance is a portion of the salary or income of Indonesian Workers (TKI) sent from abroad to their families in the country. Remittances have a positive impact on increasing financial inclusion, some studies reveal remittances as part of a form of transfer as an inclusive financial entry point (Bank Indonesia, 2019).

Studies on the impact of PMA and remittances on the economies of developing countries still produce different findings. As empirical research found a positive impact of FDI inflows on economic growth (Borensztein et al., 1998; Koko, 2006; Johnson, 2006). While others see that the impact of PMA on economic growth is insignificant (De Mello, 1999; Ali \& Mingque, 2008) or even negative (Alfaro et al., 2004). The same thing occurs in the study of remittances where some argued that remittances could drive economic growth (Giuliano \& Ruiz-Arranz, 2009; Beck \& Hassan, 2009; Chami et al., 2005; Lipton, 1980).

Issahaku \& Amidu (2018) examined two hypotheses related to remittance and economic growth about the quality of domestic institutions. The findings show that countries with poor domestic institutions will 'import' growth by attracting more remittances because their institutions are unable to support growth in other ways. Meanwhile, countries with weak domestic institu-tions will be more efficient and careful in utilizing remittances because their institutions are more likely to fail to manage remittances. In other words, the impact of remittances on a country's economic growth will be influenced by the country's capacity to absorb the remittance flows they receive (Bettin \& Zazzaro, 2011).

Nwaogu \& Ryan (2015) also carried out research related to the impact of foreign investment (PMA), foreign aid and remittances on economic growth in 53 African countries and 34 Latin American and Caribbean countries. The previous studies have produced different findings re-garding the impact of FDI, foreign aid and remittances on economic growth and development. Some find that these factors have a positive effect (Chenery \& Strout, 1966; Burnside et al., 2000; Lumbila, 2005) while others find 
them to have a negative or no impact at all (Chami et al., 2005; Mah, 2010). The explanation generally given is that the impact of each of these factors is influenced by condition variables or institutions. For example, FDI is found to increase econom-ic growth only if the FDI provides access to foreign technology (Lyroud et al., 2004); foreign aid can have a positive impact depending on how much financial liberalization is in the recipient country (Ang, 2010); remittances can have positive effects only if they are used for productive activities - not consumptive (Ekanayake \& Halkides, 2008).

Other researches about remittance was conducted by Carment \& Calleha (2018) to explain the benefit of remittance by looking further at the role of the diaspora in the context of a fragile nation. Diasporas are generally well-known 'agents of change' for development. This under-standing is based on the assumption that the global market regime has failed to ensure an equal distribution of wealth among countries in the world. In such a context, a diaspora that is not seen by the interests of the international regime and motivated by a love of the country of origin is considered capable of mobilizing resources (remittances) from developed countries to rapu countries (Koinova, 2012). Related to this case, researchers on diaspora remittances generally agree that remittances will only have a positive impact on economic growth if used for invest-ment, not for the consumption (Debass \& Ardovino, 2009).

\section{Material and Methods}

The aim of this research is to examine the impact of external factors on economic growth. Based on the availability of data, the variables used are remittances, PMTB, and imports to analyze the impact on economic growth. Empirical analysis is conducted using 31 annual observations from 1988-2018. The analytic method used in this paper is adopted from Tahir et al. (2015) as follow:

$$
G R O=b_{0}+b_{1} \text { LnRem }_{t}+b_{2} \operatorname{Imp}_{t}+b_{3} \text { PMTB }_{t}+u_{t}
$$

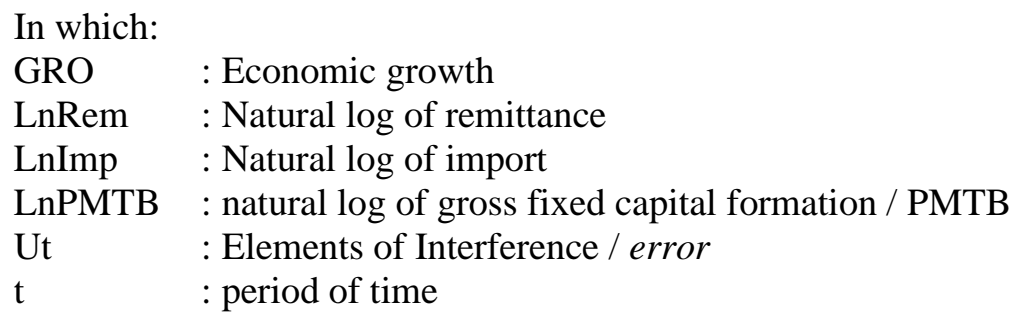

In the equation (1) variable of economic growth is used as dependent variable measured in a percent. Remittances are measured in USD billions. PMTB used to capture investment is also measured in units of billions of USD. In addition, the total import variable is measured in billions of USD. All data are obtained from World Development Indicators data.

Time series data require special cases before analyzing. The data is usually not stationary. Therefore, it is necessary to examine the data whether there is a problem of stationarity (unit root) at the level of the cointegration test. If there is a stationarity problem, then the regression will be apparent. If the time series variable is not stationary at the level, the next step is to use cointegration techniques. Cointegration test is conducted to test whether the variables which are not stationary at the data level are cointegrated between one variable with another variable. Cointegration is formed if a combination of variables that are not stationary produces a stationary variable. Cointegration techniques in the case of non-stationary data at the level can be used to detect long-term relationships. The concept of cointegration requires that et must be stationary in $\mathrm{I}(0)$ to be able to produce equilibrium in the long run.

ARDL method is one of the form of the econometrics method which was introduced by Pesaran \& Shin (1997) which was approached by cointegration test with Bound Test Cointegration. The ARDL method can be used in short series data and does not require the classification of variable estimation so that it can be done on variables I (0), I (1) or a combination of both. Thud, this paper uses a cointegration 
ARDL model to identify the existence of a long-term relationship, if the variables are not stationary. The bound testing or ARDL approach has recently begun to develop. Based on equation (1), the ARDL model constructed is as follows:

$$
\begin{aligned}
G R O_{t}= & \\
& b_{0}+b_{1}(\text { Gro })_{t-1}+b_{2}(\text { LnRem })_{t-1}+b_{3}(\text { LnImp })_{t-1}+ \\
& b_{4}(\text { LnPMTB })_{t-1}+\sum_{t=1}^{n} b_{5}(\text { Gro })_{t-1}+\sum_{i=1}^{n} b_{6}(\text { LnRem })_{t-1}+ \\
& \sum_{i=1}^{n} b_{7}(\text { LnImp })_{t-1}+\sum_{t=1}^{n} b_{8}(\text { LnPMTB })_{t-1}+u_{t}
\end{aligned}
$$

By anticipating the first step conducted in ARDL Bound Test approach to see F-statistic obtained. F-statistics obtained will explain the presence or absence of a long-term relationship between variables. The hypothesis in the $\mathrm{F}$ test is $\mathrm{H}_{0}=\alpha_{1}=\alpha_{\mathrm{n}}$ and $\mathrm{H}_{0} \neq \alpha_{1} \neq \alpha_{\mathrm{n}}$. If F-statistic value is in critical value, then it can be concluded that cointegration occurs. Meanwhile, if the F-statistic is below the lower bound, it can be concluded that cointegration does not occur. If the F-statistic is between the two critical values, the result is inconclusive.

ARDL model requires the lag as the equation (2). Selecting the right lag for the model can be chosen using the basis of Schawrtz-Bayesian Criteria (SBC), Akaike Information Criteria (AIC) or using other information criteria, a good model has the smallest criterion information value (Juanda, 2009). The next step in the ARDL method is to estimate the parameters in the short run. This can be conducted by estimating parameters in short run or short run. This is presented by estimating the Error Correction Model (ECM) model.

The next step is to develop an Error Correction Model (ECM) to identify short-term dynamics and long-term stability. Error Correction Model (ECM) is the level of error correction. A valid ECM equation must have a significant and negative ECT. According to equation (2), the Error Correction Model (ECM) model is determined as follows:

$$
\begin{aligned}
G R O_{t}= & b_{0}+\sum_{i=1}^{n} b_{1} \Delta(\text { Gro })_{t-1}+\sum_{i=1}^{n} b_{2} \Delta(\text { LnRem })_{t-1}+\sum_{i=1}^{n} b_{3} \Delta(\text { LnImp })_{t-1}+ \\
& \sum_{i=1}^{n} b_{4} \Delta(\text { LnPMTB })_{t-1}+(\text { ECM })_{t-1}+u_{t}
\end{aligned}
$$

\section{Results and Discussion \\ Stationary test}

The result of stationary test using Augmented Dickey-Fuller (ADF) test concludes that stationary remittance, import, and gross fixed capital formation (PMTB) variables at the first difference with a real level of one percent. Whereas only economic growth is stationary at the level.

Table 1. Stationary test result

\begin{tabular}{lrccc}
\hline \multicolumn{1}{c}{ Variable } & Intercept & Trend\&Interce pt & Intercept & Trend\&Interc ept \\
\hline Economic growth (GRO) & $-3.83^{* * *}$ & $-3.77^{* *}$ & $-6.77^{* * *}$ & $-6.65^{* * *}$ \\
& -1.75 & -1.69 & $-5.15^{* * *}$ & $-5.18^{* * *}$ \\
Remittance (LNREM) & -1.68 & -2.73 & $-5.11^{* * *}$ & $-5.10^{* * *}$ \\
Import (LNIMP) & & & & \\
Gross Fixed Capital & -0.68 & -2.61 & $-4.60^{* * *}$ & $-4.52^{* * *}$ \\
$\begin{array}{l}\text { Formation / PMTB } \\
\text { (LNPMTB) }\end{array}$ & & & & \\
\hline
\end{tabular}

***) **) *) stationary level of $1 \%, 5 \%$, dan $10 \%$ 


\section{Optimum lag test}

This research used Optimum Lag Test with the base value of the Akaike Information Center. In the test, there are 20 best lag combinations which can be used in this ARDL model. The best determination can be conducted by observing at the smallest criterion value. The results of the optimum lag test in this research indicate that the best lag combination for this model is econom-ic growth of lag 1, remittance of lag 1, imports of lag 4, and Gross Fixed Investment (PMTB) of lag 1.

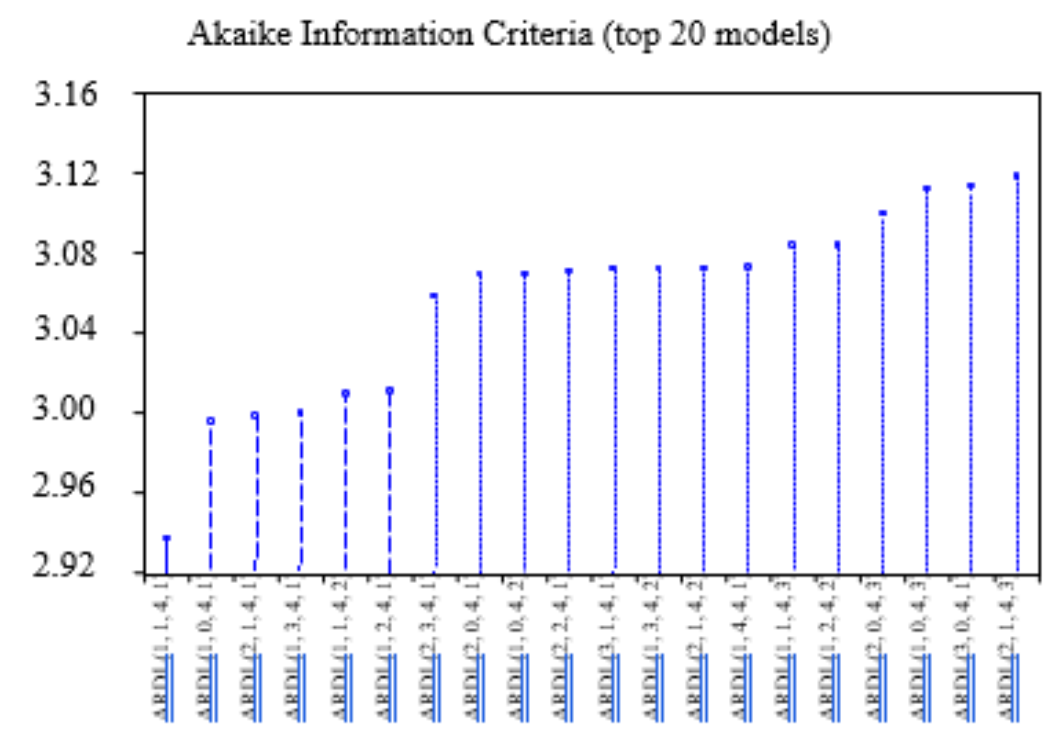

Figure 3. Optimum lag result

\section{Cointegration test}

Cointegration test is conducted to examine whether variables which are not stationary in cointegrated data level between one variable with another variable. In the ARDL model, the cointegra-tion test used is the Bound Test. Bound Test results show an F-Statistic of 38.90 and a value greater than the upper bound (5.61). Thus, it can be concluded that there is cointegration in the model.

Table 2. Cointegration test result

\begin{tabular}{ccc}
\hline Statistic Test & Value & $\mathrm{K}$ \\
\hline F-Statistic & 38.90 & 3 \\
\hline & Critical Value Bounds \\
\hline Significance & I (0) Bounds & I (1) Bounds \\
\hline $10 \%$ & 2.72 & 3.77 \\
$5 \%$ & 3.23 & 4.35 \\
$2.5 \%$ & 3.69 & 4.89 \\
$1 \%$ & 4.29 & 5.61 \\
\hline
\end{tabular}

\section{Stability test}

Plot of cumlative sum (CUSUM) and cumulative sum of squares (CUSUMQ) indicate the stability of the coefficient of the variables used in the model. The results of the CUSUM and CUSUMQ plots from the recursive estimation of the model indicate the stability of the variabels in the period in this research. 

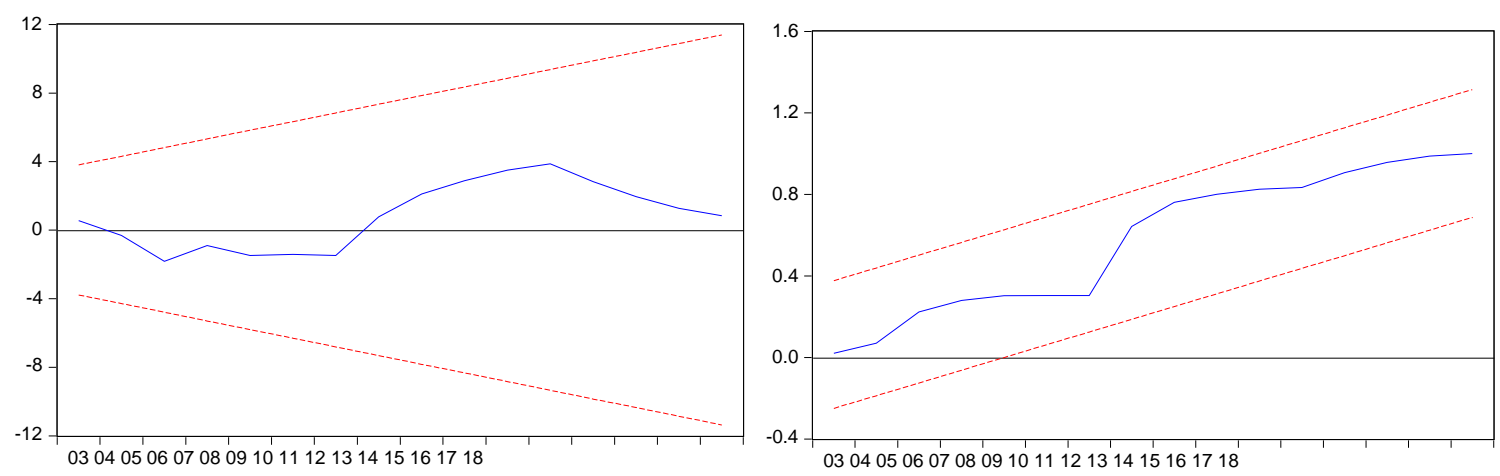

Figure 4. Stability test plot of CUSUM and CUSUMQ

\section{Classic assumption test}

R-Squared value in AEDL model is 0.966. it shows that the diversity of the model can be explained by the independent variable by $97 \%$, while the rest is influenced by other variables outside the model. $\mathrm{P}$ value indicates a value of less than 5\%. Thus, it can be concluded that all independent variables significantly influence the dependent variable. Regression in this ARDL model has required the classical assumption test, such as serial correlation test, heteroscedasticity test, and normality test. Table 3 shows the results of the clas-sic assumption test on this ARDL model.

Table 3. Classic assumption test result

$$
\text { t-statistic P-Value }
$$

\begin{tabular}{lll}
\cline { 2 - 2 } Serial Correlation & 0.686650 & {$[0.519]$} \\
Heteroskedasticity & 0.448965 & {$[0.899]$} \\
Normality & 1.420556 & {$[0.492]$} \\
\hline R-Square & 0.966 & \\
Adjusted R-Square & 0.944 & \\
Prob (F-Statistics) & 0.000 & \\
\hline
\end{tabular}

\section{ARDL estimation result}

\section{Long-term model estimation}

In the last part, it can be conducted ARDL model estimation because there is a long-term relationship (cointegration) of the variables used. Furthermore, it is estimating and identifying the long-term relationship between the independent variable and the dependent variable. Table 4 shows that there is a significant long-term effect on the real level of five percent of the inde-pendent variables which are remittance, PMTB, and imports on the independent variable of eco-nomic growth. The coefficient on each independent variable shows that the variable affects eco-nomic growth. 
Table 4. Long-term coefficient

\begin{tabular}{lll}
\hline Variables & coefficients & probability \\
\hline LNREM & 1.02 & 0.05 \\
LNIMP & -9.95 & 0.05 \\
LNPMTB & 7.45 & 0.00 \\
C & 41.95 & 0.12 \\
\hline
\end{tabular}

Source: Processed result of Eviews 9

Remittance is given the benefit to the economic of Indonesia. The remittance variable signif-icantly affects economic growth at the 5\% level. The effect of remittance receipts on economic growth of 1.02 . It means that each change in remittance receipts increases by 1 percent. Besides, economic growth will increase by 1.02 percent. This result is in line with the survey of Indone-sian Migrant Workers (PMI) conducted by the World Bank in collaboration with the Central Sta-tistics Agency. Remittances contribute to improving the lives of both migrant workers and their families. About 40 percent of migrant worker households use their remittance income for educa-tion, 15 percent invest it in venture capital, and more than 20 percent keep it in a savings ac-count (World Bank, 2017). These results indicate that PMI has considered the continuity of life in the future by setting aside the receipt of remittances for investment both in education and business. Remittance remittances can also assist stabilize the national economy through in-creased foreign exchange reserves. Indonesia is a country which is quite rich in the workforce because of its high population. With the decentralization policy that is currently being implemented, it is expected that PMI will become a State asset which must be prioritized. The close relations with Indonesia with oil-rich countries such as the Middle East must also be increased to support the success of PMI.

Besides the remittance acceptance, the variable gross fixed capital formation (PMTB) has a positive influence on economic growth in the long run. The effect of PMTB variable on eco-nomic growth is 7.45. It is that each increase in the formation of fixed capital of 1 percent, then economic growth will increase by 7.45 percent. Capital formation directly affects the economy of a country. Thus, the effect of increasing PMTB on economic growth affects both the short and long term. These results are in line with the neoclassical growth model, that economic growth is affected by physical capital and human capital (Solow, 1956; Mankiw et al., 1992).

In contrast to the import variable, in the long run increasing imports will reduce economic growth. The import variable is -9.95. It that if imports increase by 1 percent, then economic growth will decrease by 9.95 percent. Import activities indirectly send money abroad so there is a capital outflow. Increased import activities that are not offset by an increase in export activities will result in a negative trade balance. If the condition of the trade balance is negative, it will cause Gross Domestic Product (GDP/PDB).

\section{Estimation of long-term model}

Based on short-term relation test result by using Error Correction Model (ECM), all inde-pendent variables are significant to the dependent variable except remittance. The error correc-tion term (CointEq) value of- 1.28 and significant at the 0.000 level indicates that the disequilib-rium of the previous period is corrected at the current period of $1.28 \%$. Error correction term indicates how quickly equilibrium is reached to long-term balance.

In short-term, all variable affects significantly toward economic growth except remittances. Although it has no significant effect statistically, the receipt of remittances in the short term is negatively related to economic growth. Bettin \& Zazzaro, 2011 stated that remittances will have a positive impact on economic growth if used for investment and become negative if used for consumption. Thus, the impact of remittances on economic growth will depend on how the re-mittances are used. 
Table 5. Short-term coefficient

\begin{tabular}{lll}
\hline Variables & coefficients & probability \\
\hline$\Delta($ LNREM $)$ & -0.37 & 0.71 \\
$\Delta($ LNIMP $)$ & -9.51 & 0.00 \\
$\Delta($ LNIMP(-1) $)$ & 2.90 & 0.17 \\
$\Delta($ LNIMP(-2) & 1.71 & 0.36 \\
$\Delta($ LNIMP(-3)) & 3.56 & 0.02 \\
$\Delta($ LNPMTB $)$ & 41.75 & 0.00 \\
CointEq(-1) & -1.28 & 0.00 \\
\hline
\end{tabular}

Cointeq $=$ GRO $-(1.0196 *$ REM $-9.94658 *$ IMP $+7.4550 *$ PMTB +41.9518$)$

\section{Conclusion and Recommendation}

The main aim of this paper is to find out external factors such as remittances, imports, and PMTB on economic growth in Indonesia. This paper focuses on the economy in Indonesia using time series data for the period 1988-2018. Empirical analysis was performed using the econometric model, namely the cointegration ARDL regression.

This paper finds that external factors which are important for achieving long-term economic growth. Remittance and PMTB shipments have been proven to significantly improve economic growth in Indonesia. The use of more productive remittance receipts, which are used for investment both in education and business. It has been proven to contribute to long-term economic growth. However, the receipt of remittances does not affect economic growth in the short term. The PMTB variable significantly influences economic growth both in the short and long term. This is certainly due to the variable related to investment so that it is directly related to economic growth. Import variables are positively related to economic growth in the short term because they can act as price stabilizers, especially for imported goods. While in the long run, the import variable has a negative effect because import growth is higher than export growth, causing a current account deficit that has an impact on reducing economic growth.

This paper gives recommendation that government needs to maintain the investment climate to support economic growth. It finds the receipt of remittances as having a positive impact on economic growth in the long run. Thus, the government needs to focus on improving the Migration sector by increasing the quality of PMI of the professionalization of the workforce. Easing documents is also needed to reduce illegal PMs. The government also needs to increase protection for PMI abroad. In addition, after the return of PMI from abroad the government needs to provide guidance in order to be able to maintain the benefits of migratory activities. Considering that PMI works a lot in the Middle East countries, it needs to be an increase in work between countries to ensure a better life for PMI when migrating. Innovative industrialization needs to be conducted by the government to encourage the investment climate and increase exports which have value added and high competitiveness.

\section{Acknowledgment}

We would like to thank all those who have helped to complete this article.

\section{References}

Alfaro, L., Chandra, A., Kalemli-Ozcan, S., \& Sayek, S. (2004). FDI and economic growth: The role of local financial markets, Journal of International Economics, 64(1), 89-112.

Ali, N., \& Mingque, Y. (2018). Does foreign direct investment lead to economic growth? Evidence from developing countries. International Journal of Economics and Finance, 10(3), 109-119.

Ang, J. (2010). Does foreign aid promote growth? Exploring the role of financial liberalization. Review of Development Economics, 14, 197212.

Bank Indonesia. (2019). Retrieved from bi.go.id: http://www.bi.go.id/id/publikasi/laporan-tahunan/bi/pages/LKTBI-2018.aspx

Beck, T., Demirgeuc-Kunt, A., \& Levine, R. (2007). Finance, inequality, and the poor. Journal of Economic Growth, 12, 27-49. 
Bettin, G., \& Zazzaro, A. (2011). Remittances and financial development: Substitutes or complement in economic growth, Bulletin of Economic Research, 64(4), 509-536.

Borensztein, E., De Gregorio, J., \& Lee, J. W. (1998). How does foreign direct investment affect economic growth. Journal of International Economics, 45(1), 115-135.

Burke, P. J., \& Siyaranamual, M. D. (2019). No one left behind in Indonesia. Bulletin of Indonesian Economic Studies, 55(3), $269-293$.

Burnside, Craig, \& David, D. (2000). Aid, policies, and growth. American Economic Review, 90(2000), 847-868.

Carment, D., \& Calleja, R. (2018). Diasporas and fragile states-beyond remittances assessing the theoretical and policy linkages. Journal of Ethnic and Migration Studies, 44(8), 1270-1288.

Chami, R., Fullenkamp, C., \& Jahjah, S. (2005). Are immigrant remittance flows a source of capital for development. IMF Staff Papers, 52(1), 55-81.

Chenery, Hollis, B., \& Alan, M. S. (1966). Foreign assistance and economic development. American Economic Review, 52(2005), 55-81.

De Mello, R. (1999). Foreign direct investment led growth: Evidance from time series and panel data. Oxford Economics Papers, 51, $133-151$.

Debass, T., \& Ardovino, M. (2009). Diaspora Direct Investment (DDI): The untapped resource for development. United States: States Agency for International Development.

Driffield, N., \& Chris, J. (2013). Impact of FDI, ODA and migrant remmittance on economic growth in developing countries: A system approach. European Journal of Development Research, 25, 173-196.

Ekanayake, E. M., \& Mihaalis, H. (2008). Do remittances and foreign direct investment promote growth? Evidence from developing countries. Journal of International Business and Economics, 8, 58-68.

Giuliano, P., \& Ruiz-Arranz, M. (2009). Remittances, financial development, and growth. Journal of Development Economics, 90(1), 144-152.

Issahaku, H., Abor, J. Y., \& Amidu, M. (2018). The effects of remittances on economic growth: Reexamining the role of institutions. The Journal of Developing Areas, 52(4), 29-46.

Johnson, A. (2006). The effects of FDI inflows on host country economic growth. CESIS Electronic Working Paper Series, Paper, 58, 1-5.

Juanda, B. (2009). Ekonometrika pemodelan dan pendugaan. Bogor: IPB Pr.

Koinova, M. (2012). Autonomy and positionality in diaspora politics. International Political Sociology, 6(1), 99-103.

Koko, A. (2006). The home country effects of FDI in developed economies. European Institute of Japanese Studies, Stockholm School of Economics Working Paper, 225,1-10.

Lipton, M. (1980). Migration from rural areas of poor countries: The impact on rural productivity and income distribution. World Development, $8(1), 1-24$

Lumbila, \& Kevin, N. (2005). What makes FDI work? A panel anaysis of the growth effect of FDI in Africa. Wahington, DC: World Bank.

Lyroudi, Katerina, Jhon, P., \& Athanasious, V. (2004). Foreign direct investment and economic growth in transition economies. South-Eastern Europe Journal of Economics, 1, 97-110.

Mah, J. (2010). Foreign direct investment inflows and economic growth: The case of Korea. Review of Development Economics, 14, 275-304.

Mankiw, N. G., Romer, D., \& Weil, N. D. (1992). A contribution to the empiris of economic growth. The Quarterly Journal of Economics, 107(2), 407-437

Nwaogu, U. G., \& Ryan, M. J. (2015). FDI, foreign aid, remittance and economic growth in developing countries. Review of Development Economics, 19(1), 100-115.

Pesaran, \& Shin. (1997). Working with Microfit 4.0 interactive econometric analysis. Oxford University Press.

Sharma, B. (2018). Socio-economic Problems of Remittance Economy: The Case of Nepal. Journal of Advanced Management Science, 5(4), 285-290.

Sinha, M., Tirtosuharto, D., \& Sengupta, P. P. (2019). Impact of FDI and Remittance Inflows in Developing Asia: A Comparative Dynamic Panel Study. Economic Papers, 1-18.

Solow, R. M. (1956). A contribution to the theory of economic growth. The Quarterly Journal of Economics, 70(1), 65-94.

Tahir, M., Khan, I., \& Shah, A. M. (2015). Foreign remmittances, foreign direct investment, Foreign imports and economic growth in Pakistan, A Time Series Analysis. Arab Economics and Business Journal, 82-89

World Bank. (2019). wdi.worldbank.org. Retrieved from http://databank.worldbank.org/data/ 